\title{
EBV Positivity and Programmed Death-ligand 1 Expression in Diffuse Large B-cell Lymphoma: A Systematic Review
}

\author{
GABRIELA ANNA BARZYK ${ }^{1}$ and VAFIE SHERIFF ${ }^{2}$ \\ ${ }^{l}$ Warwick Medical School, University of Warwick, Coventry, U.K.; \\ ${ }^{2}$ Institute of Medical and Biomedical Education, St George's University of London, London, U.K.
}

\begin{abstract}
Background/Aim: Diffuse large B-cell lymphoma (DLBCL) is the most common form of non-Hodgkin lymphoma. A systematic review to evaluate the association between Epstein-Barr Virus (EBV) and programmed death ligand-1 (PD-L1) in DLBCL biopsy was conducted. Materials and Methods: Only studies comparing EBV+ and EBV- groups were eligible following database search. Prevalence ratios were calculated for results comparison. The EBV impact on PD-L1 positivity in tumour cells and its microenvironment was analysed. Results: With 270 records screened, eleven crosssectional studies were identified for final review. Eight studies investigated PD-L1 expression in tumour cells and found an $E B V$ trend unlikely, while four studies found an increase in its expression in the tumour microenvironment. Nine studies showed that $E B V+$ cases were more commonly of non-germinal centre B-cell origin. Four studies examined genetic aberrations, but no definite consensus was reached. Conclusion: A non-EBV related mechanism is likely related to increased PD-L1 expression, with relevance to the cell of origin.
\end{abstract}

Diffuse large B-cell lymphoma (DLBCL) is the most common form of Non-Hodgkin Lymphoma (NHL) and represents $25-45 \%$ of NHL globally (1). With annual incidence of 5-7 per 100,000 people, age is a significant factor as incidence rises to around 30 per 100,000 in those aged 65-84 years (2). DLBCL, not otherwise specified

This article is freely accessible online.

Correspondence to: GA Barzyk, Warwick Medical School, University of Warwick, Coventry CV4 7AL, U.K. Tel: +44 7493881486,e-mail: gbarzyk@outlook.com

Key Words: EBV, diffuse large b-cell lymphoma, Epstein-Barr virus positive diffuse large b-cell lymphoma, programmed death-ligand 1, tumour immunology, non-Hodgkin lymphoma, review.
(DLBCL, NOS) accounts for $80-85 \%$ of all DLBCL cases and its diagnosis is made via exclusion of DLBCL subtypes with a distinct morphology or immunophenotype (3). Herein, DLBCL and DLBCL, NOS are interchangeable terms in literature unless a distinct subtype of DLBCL is specified.

DLBCL typically arises at a lymph node, although extranodal manifestations are also present (4). Its aetiology remains poorly understood, but changes in gene expression and mutations which promote malignant behaviour have been noted (5). DLBCL is diagnosed via biopsy, where tumours derived from germinal centre B-cells (GCB) have a better prognosis than those of non-GCB (N-GCB) subtype, also known as Activated B-cells (ABC) (6). Despite advancements, approximately $40 \%$ of patients relapse or are refractory (7) to standard R-CHOP treatment (Rituximab, cyclophosphamide, hydroxydoxorubicin, oncovin and prednisolone/prednisone), where the presence of Epstein-Barr Virus (EBV) appears to coincide with more severe outcomes (8).

DLBCL has undergone a major revision in the World Health Organisation (WHO) 2016 classification of lymphoid neoplasms, including renaming of "EBV-positive DLBCL of the elderly" subtype to "EBV-positive DLBCL, NOS" as younger individuals can also be affected (9). Approximately $90-95 \%$ of the world's population sustains a life-long, asymptomatic infection with EBV through saliva (10), following a primary lytic infection, where the virus avoids immune response by acquiring various latency types (11). About $5-15 \%$ of all DLBCL cases are EBV positive (EBV+) (12) and higher incidence rates are found in developing countries (13) where both immunocompetent and immunocompromised patients are affected (14).

EBV association has been increasingly analysed in articles exploring programmed cell death protein-1 (PD-1) (2q37.3 locus) and programmed death-ligand 1 (PD-L1) (9p24.1 locus). PD-1 is normally expressed on the surface of immune cells and it has the ability to negatively regulate the immune response. In cancerous state, PD-L1 present on a cancer cell 
binds to PD-1, thus reducing T-cell function and preventing immune response (15) leading to immune evasion. PD-1 blockade has been established as a therapy for some cancers (16), and PD-L1 has been found to be over-expressed in various DLBCL tumours, prolonging tumour progression and survival (17). The precise mechanism(s) involved in EBVdriven DLBCL carcinogenesis remain unknown (18) and up to date EBV trends related to DLBCL PD-L1 expression have not been summarised. Accordingly, a systematic review was carried out to evaluate available literature to determine whether EBV positivity has an impact on PD-L1 expression in DLBCL tumour biopsy.

\section{Materials and Methods}

This systematic review was registered with PROSPERO, an international prospective register of systematic reviews (registration ID: CRD42020183091).

Search strategy. A search of the published literature was carried out on $25^{\text {th }}$ of April 2020 using Embase, LILACS, Web of Science, CINAHL, Ovid, National Cancer Institute, Cochrane Central Register of Controlled Trials (CENTRAL), EU Clinical Trials Register and ClinicalTrials.gov databases. The search terms relating to EBV ("EBV" OR "Epstein Barr Virus" OR "HHV4" OR "EBER" OR "LMP" or "EBNA"), DLBCL ("lymphoma" OR "b-cell lymphoma" OR "DLBCL" OR "diffuse large b-cell lymphoma") and PD-L1 ("PD-L1" OR "PDL1" OR "CD274" OR "programmed death-ligand 1" or OR "b7-h1" OR "PDCD1LG1") were adapted to each database, and limited to publication date of 2015 to present. In addition, article reference lists were reviewed to ensure thorough search of the literature.

Eligibility criteria. The EPICOT framework (evidence, population, intervention, comparison, outcome, timestamp) (19), was used to develop the research question and to formulate inclusion criteria to select appropriate studies. Studies were selected if they met the following requirements: 1) Discuss $\mathrm{EBV}+\mathrm{DLBCL}$ and/or their extranodal manifestations, include DLBCL classified within lymphoproliferative disorder, post-transplant or immunocompromised patients. Provide analysis relevant to PD-L1 expression or therapy, whether in the tumour itself or in the tumour microenvironment; 2) Studies including minimum of $\geq 10$ participants, 5 of which were in the EBV+ DLBCL subgroup and 5 in the control group; 3) Articles discussing tumour biopsy, whether archival or with sample obtained during study. Specific treatment(s) not required, but any intervention or study looking at genetic alterations, molecular application or drug therapies which affect PD-L1 expression to be noted; 4) Have a control group of EBV- DLBCL patients; 5) Describe EBV status identification or confirmation, accept expression and/or genetic identification of EBER, EBNA or LMP. PD-L1 identification explicitly stated and justification for positivity status provided. Offer a comparison between EBV+ and EBV-subgroups; 6) Papers with publication date 2015 onwards, with first author known, full-text article available and any conflict of interest is explicitly stated. Exclusion criteria included the following: 1) Papers discussing other distinct DLBCL subtypes or distinct clinical issues including chronic inflammation associated DLBCL or primary lymphoma of the central nervous system, addressing EBV-related B-cell neoplasms classed as: Burkitt, Hodgkin, plasmablastic or primary effusion lymphomas, discussing "gray zone" lymphomas, T-cell lymphomas or leukaemias. Papers discussing PD-1 expression only, without addressing PD-L1. Any data relating to cell culture, animal studies, case studies, editorials, abstracts; 2) Papers including patients who's EBV status was not known or where data was mixed with other population subgroups where DLBCL relevant data cannot be extracted; 3) Research describing the already established standard R-CHOP treatment for DLBCL, unless new context is added with relevance to effect on PD-L1 expression; 4) Presence of EBV+ or EBV- DLBCL group only; 5) EBV or PD-L1 Identification methods or positivity criteria not stated; 6) The articles were in non-English language.

Study selection and data extraction. Two independent reviewers were involved in the study selection and any disagreement was resolved through conference with a 3 rd reviewer. The results were recorded in a PRISMA flow diagram (20), alongside a summary of reasons for exclusion.

An Excel data extraction tool was devised to facilitate comparisons and to aid data collection consistency. The following items were extracted: study design, ethical approval, sample type, sample size, methods of identification and measurement of EBV and PD-L1 including dilution factor and antibody source, positivity thresholds, expression values and supporting statements, significance values and statistical analysis methods. Obtained population characteristics included: age, gender, cell of origin, Lymphoma International Prognostic Index (IPI) and chemotherapy treatment.

Quality assessment. The critical Appraisal Tool for Cross-sectional Studies (AXIS) (21) was used to assess the quality of the included studies by the two reviewers. Each item was graded as "low risk" or "high risk", while insufficient information was classified as "uncertain".

Data synthesis. A narrative synthesis was carried out using tables summarising study characteristics and results of individual studies. The principal summary measures included data relevant to PD-L1 expression in tumour and tumour microenvironment alongside data related to genetic alterations. Where applicable, prevalence ratio (PR) was calculated with $95 \%$ confidence intervals to give general commonality to results, particularly where statistical analysis was not present, in order to evaluate EBV association with PD-L1 expression in DLBCL.

\section{Results}

Study selection. The database search identified 345 records for screening alongside 21 additional records (Figure 1). Following duplicate removal, 270 studies underwent title and abstract screening, where 105 records were excluded. A total of 165 studies underwent full text screening and eleven studies met the inclusion criteria for review.

Characteristics of included studies. The characteristics of the included studies are summarised in Table I. All eleven articles (22-32) were cross-sectional studies published between 2015 and 2019. Four articles originated from Japan (24, 28-30), 


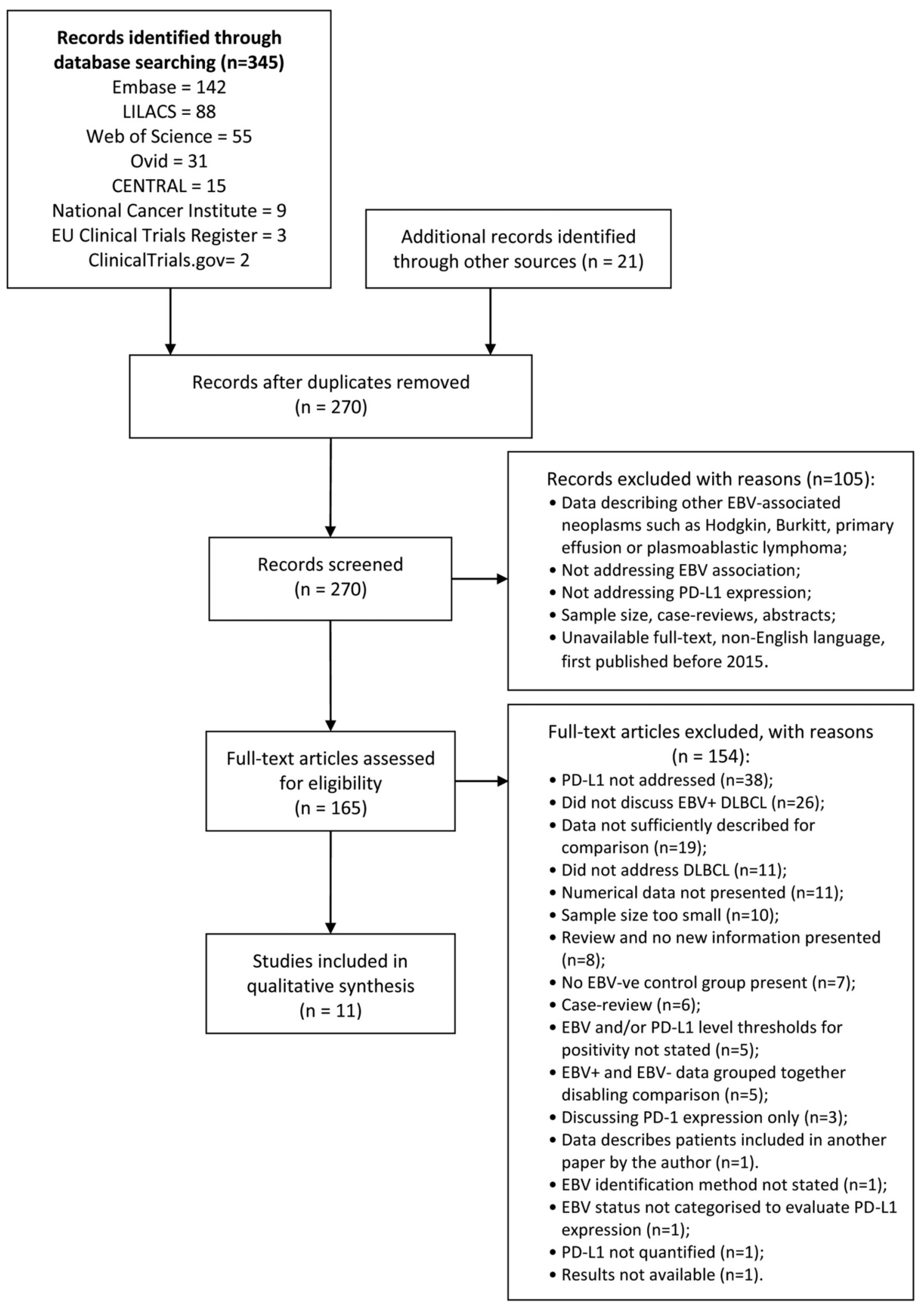

Figure 1. PRISMA Flow Diagram (20) showing the stages of the review process, alongside lists of reasons for exclusion before the final number of included studies was reached. 


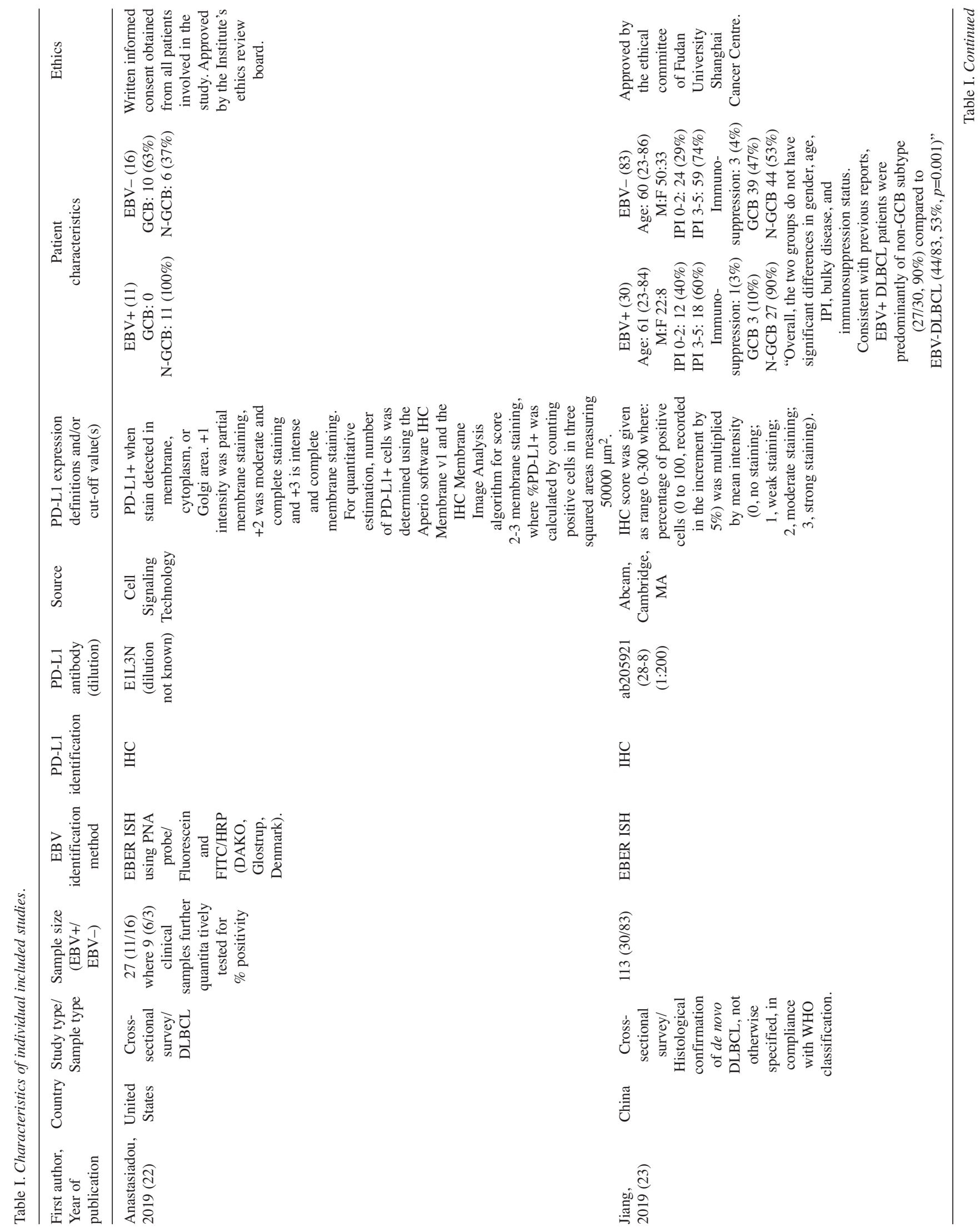




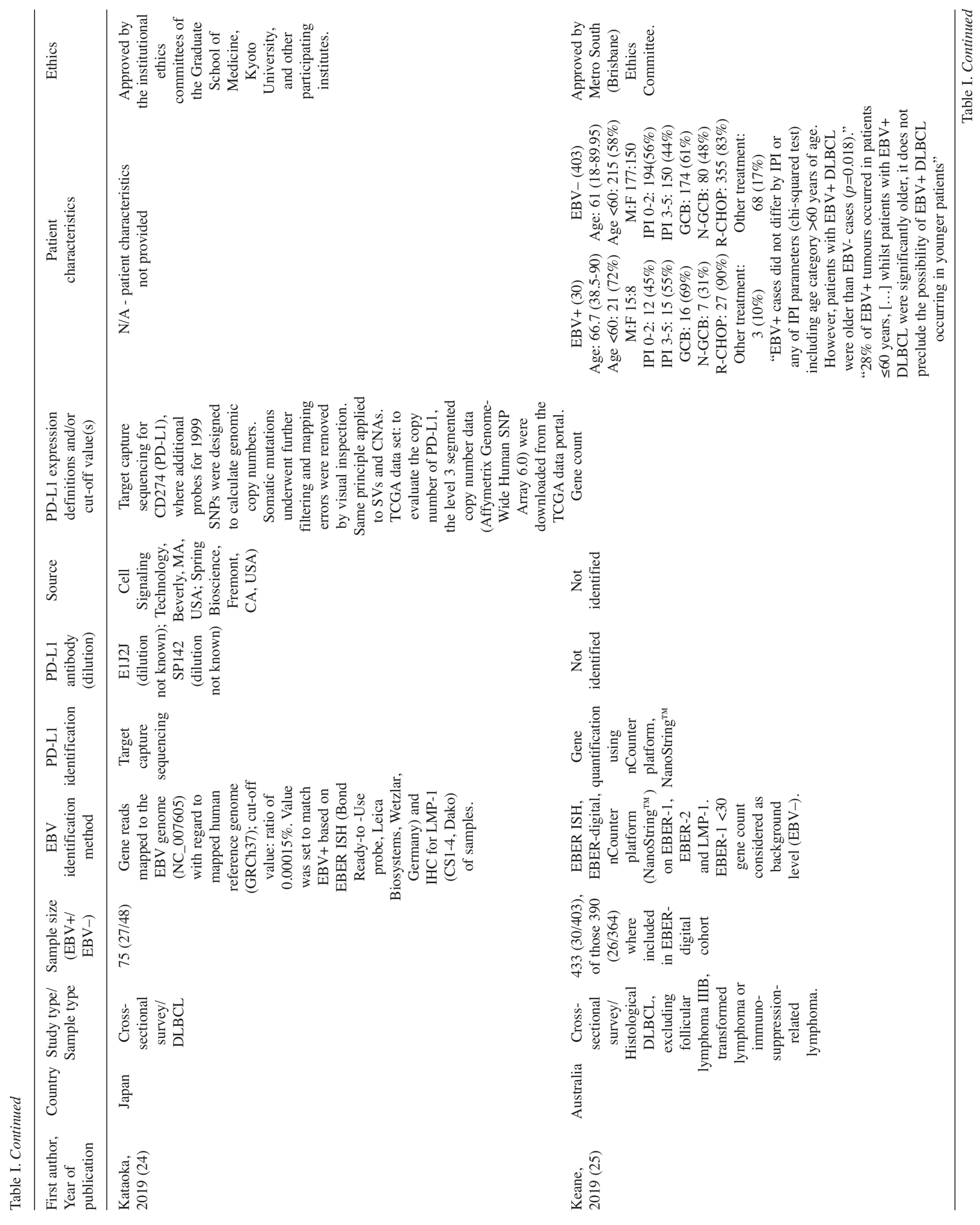




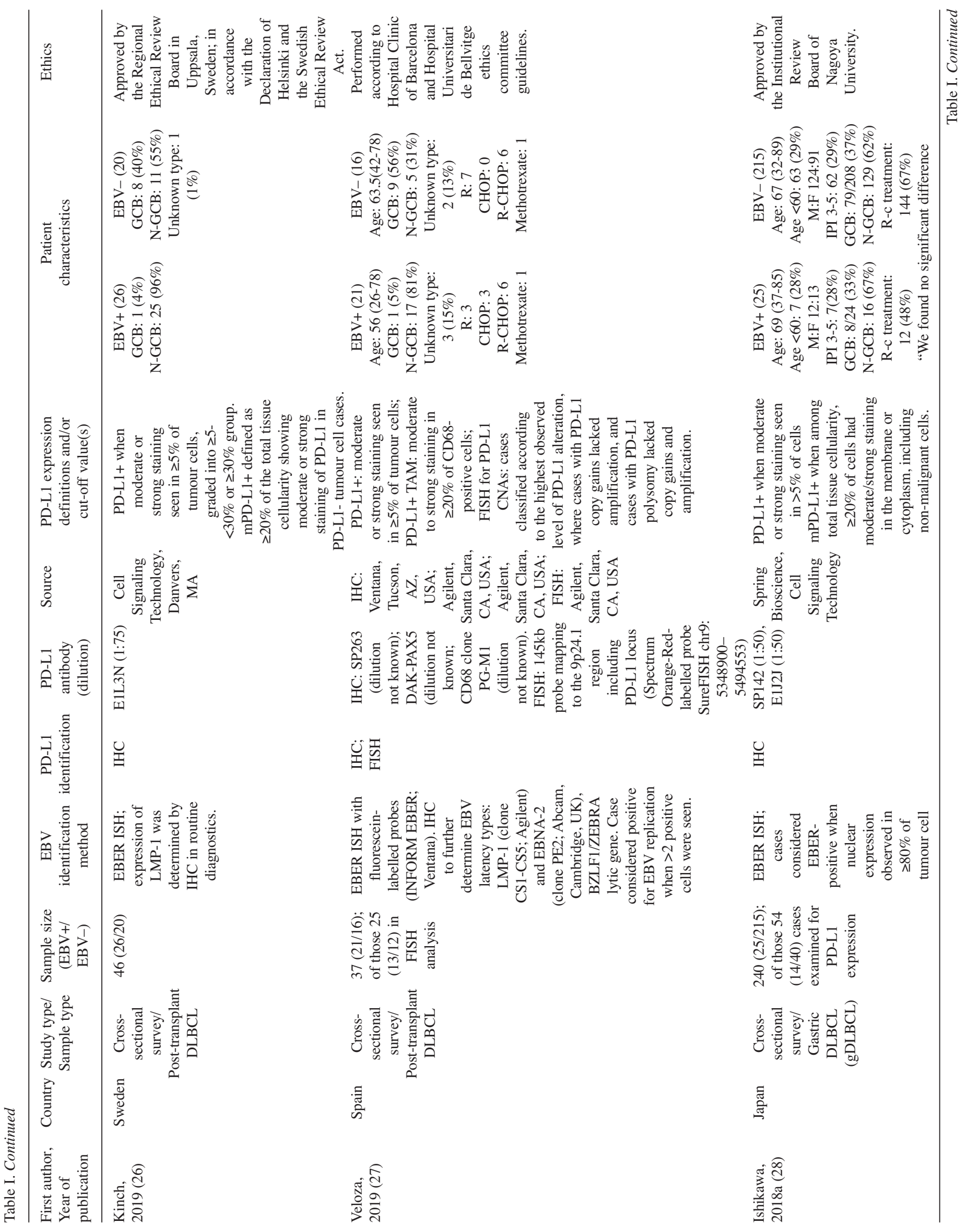




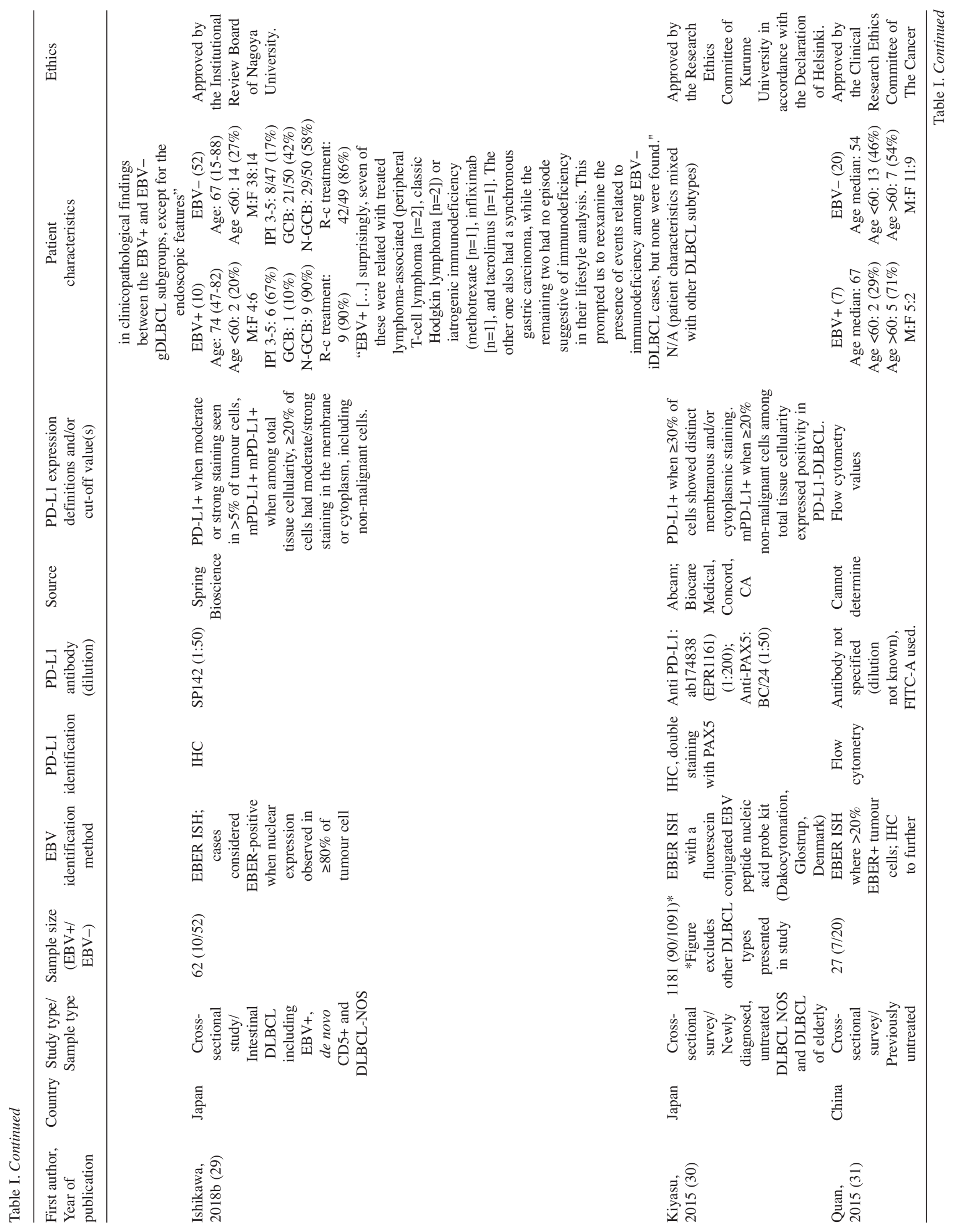




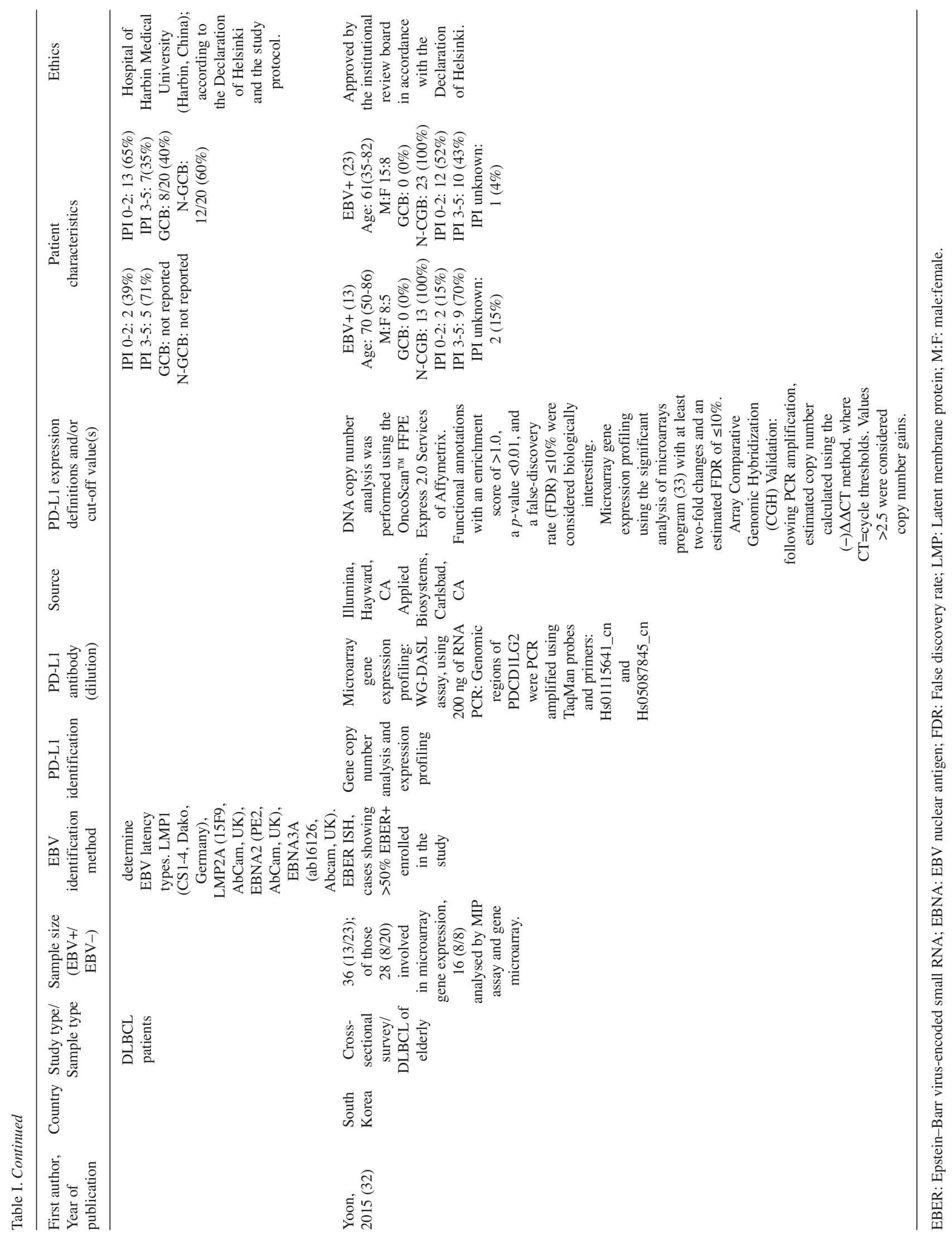


two from China $(23,31)$, and five articles originated from each of the following countries: United States (22), Australia (25), Sweden (26), Spain (27), and South Korea (32). Although all papers addressed DLBCL, there was a variation in its assortment, with two papers referring to 'DLBCL' only $(22,24)$ while others further specified the DLBCL sample type. Two papers $(31,32)$ referred to 'DLBCL of the elderly' due to publication date of 2015 , which occurred before the WHO 2016 classification update. All studies used existing records to retrospectively select DLBCL participants. Out of 2,277 cases described with patient characteristics, 2,044 samples were PD-L1 tested including $272 \mathrm{EBV}+$ and 1,772 EBV- cases. Sample size varied between 27-1181 participants. Ten studies addressed EBV+ cohort with $n=7-30$ patients, and one had an $n=90$ cohort (30). The EBV- cohort ranged from $n=16-1091$, with two studies having an $n>100$ control cohort $(25,28)$.

Patient characteristics were described to varied degree, and most were not equally distributed within and between studies. Three articles (25, 28-29) addressed all relevant characteristics relating to age, gender, cell of origin, IPI and chemotherapy treatment, none were provided within one study (24), and in one (30) the characteristics were mixed with other lymphomas, hence, were not included in this review. When cell of origin proportions were combined from nine studies addressing this parameter $(22-23,25-29,31,32)$ where 850 samples were addressed, the overall proportion for $\mathrm{EBV}+$ cases was $0.19 \mathrm{GCB}$ and $0.81 \mathrm{~N}-\mathrm{GCB}$, while EBVcases was $0.50 \mathrm{GCB}$ and $0.50 \mathrm{~N}-\mathrm{GCB}$. Seven studies addressed age $(23,25,27-29,31,32)$, and the median age for $\mathrm{EBV}+$ groups ranged from 56 to 74 while for EBV- cases it ranged from 54 to 67; patients with an age of $<60$ years were included in four studies $(25,28-29,31)$. Gender was addressed by six studies $(23,25,28-29,31,32)$ where 805 samples were distinguished (466 males and 339 females), with overall male to female ratio (M:F) of 1.37. Of the six studies addressing IPI $(23,25,28-29,31,32)$, EBV+ cases were of higher proportion in four out of six studies $(25,29$, 31,32 ) looking at IPI $3-5$, with one study noting marginal difference in proportion between EBV+ and EBV- cases (28). Four studies specified chemotherapy approach $(27,29-$ 31) relating to the patient characteristics and therapies were predominantly of Rituximab-containing nature.

EBV-encoded small RNAs (EBER) in situ hybridization (ISH) was applied in eleven studies, while two also applied genetic analysis (24-25). Overall, seven studies examined PDL1+ expression via immunohistochemistry (IHC) staining (2223, 26-30), four papers applied genetic analysis (24-25, 27 , 32) and one utilised flow cytometry (31). A combination of IHC and genetic analysis was used in one study (27).

Risk of bias assessment. Quality assessment was based on the AXIS tool (21) with exclusion of questions 3, 13 and 14 which did not apply to the participants as non-responders were not associated with any of the studies.

The quality and clarity of reporting relating to various parameters of AXIS including design, measures and conclusions were uniform across multiple studies. Study design was appropriate in all articles, however, due to relative rarity of EBV+ DLBCL, sample size justification was not provided in seven studies $(22,24,27-29,31,32)$, while four stated small sample size $(23,25-26,30)$. All studies defined their population and had an appropriate sample frame. One study did not address its aims/objectives (23) while the participant selection process was not explained in sufficient detail in three studies $(22,31,32)$, omitting details such as dates of retrospective record inclusion. Appropriate measures were incorporated in all studies and they were all measured correctly, with adequate data and methods, whether in main text or supplementary data. The statistical significance criterion was not applied to two studies $(26,30)$ as statistical analysis relevant to DLBCL was mixed with other lymphoma types, while another two $(25,27)$ did not address the reasons behind missing results. Study limitations were not addressed in three studies $(24,31,32)$, whereas only three stated no funding or conflict of interest (28-30). Overall, all studies included ethical approval and were judged as low risk for selective outcome reporting as links between funding sources and flaws in reporting were not identified.

Results of individual studies. Table of results was compiled before undertaking thematic analysis. The analysis incorporated data relevant to PD-L1 expression in tumour cell, tumour microenvironment and genetic alterations. Alongside this, a trend regarding cell of origin type in EBV+ and EBV- cases was investigated.

\section{EBV status and PD-L1 positivity}

Tumour cells. Eight studies addressed PD-L1 expression on tumour cells $(22-23,26-31)$ (Table II) where two provided statistical analysis $(23,29)$. Seven articles $(22-23,26-27,29$ 31 ) found that EBV+ showed an increase in PD-L1, and one detected no PD-L1 expression (28). Importantly, in six papers where PR was applied, only three had $P R>1$ with $95 \% \mathrm{CI}(22,27,30)$, while three papers included $\mathrm{PR}=1$ in $\mathrm{CI}$ $(26,29,31)$.

Four articles (26-29) utilised 5\% threshold for positivity, and three found an increase in PD-L1+ on EBV+ biopsies. One paper provided $p$-value: 0.072 (29), although this included $P R=1$ and a statement that PD-L1 and EBV were independent factors. Two other papers $(26,27)$ also showed $\mathrm{PR}>1$ where one included $\mathrm{PR}=1$ in CI (29), while another found that PD-L1 was not expressed on any EBV+/- tumour cells (28). Another study (30) utilised percentage expression with $>30 \%$ threshold and found that PD-L1+ was expressed in $\mathrm{EBV}+$ cases with PR 1.75 (1.04, 2.93). 
Table II. PD-L1+ expression on tumour cells based on staining patterns in eight included studies.

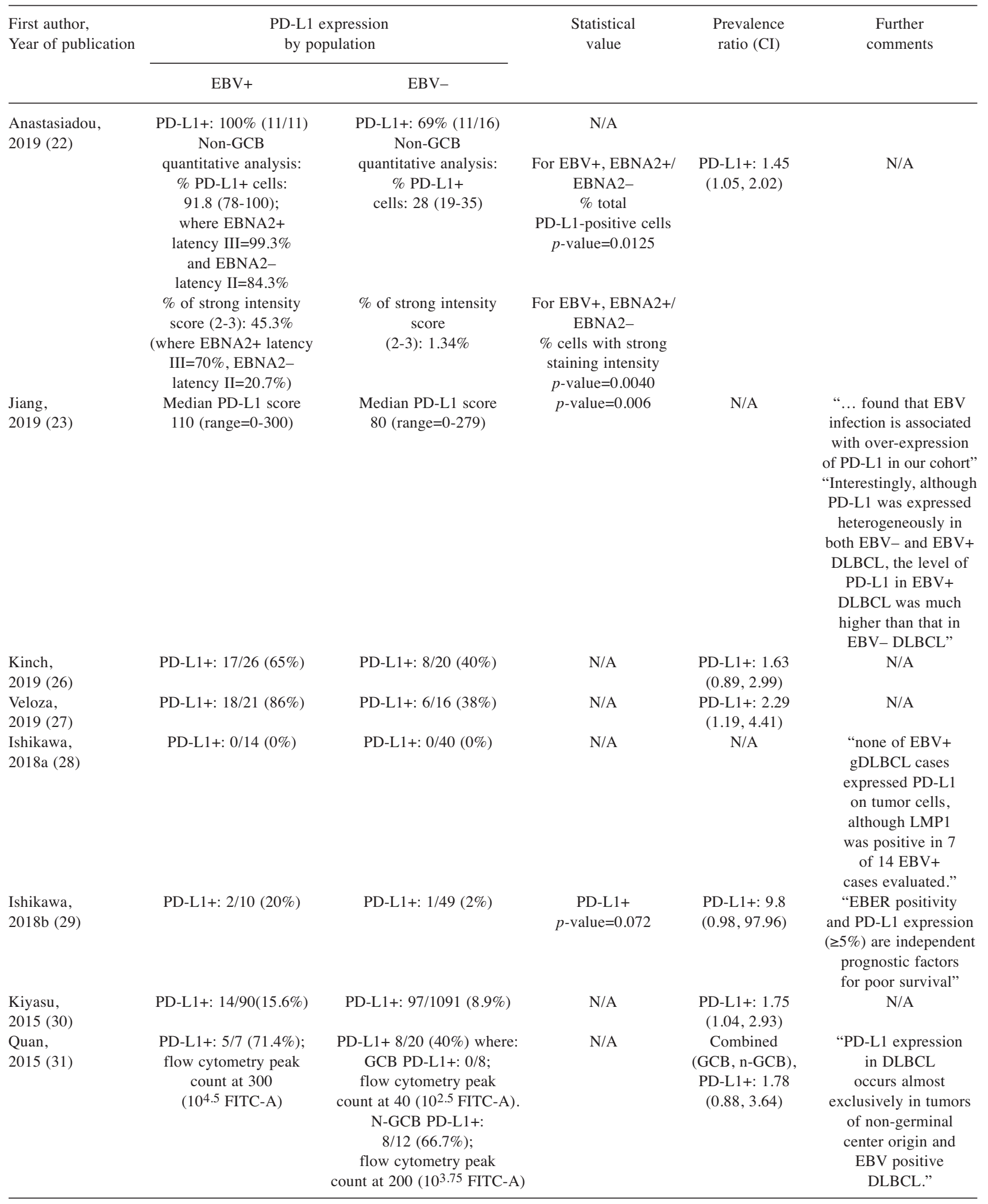

N/A: Not applicable. 
Barzyk and Sheriff: EBV Positivity and PD-L1 Expression in DLBCL (Review)

Table III. PD-L1+ expression in the tumor microenvironment based on staining patterns in five included studies.

\begin{tabular}{|c|c|c|c|c|c|}
\hline \multirow[t]{2}{*}{$\begin{array}{l}\text { First author, } \\
\text { Year of publication }\end{array}$} & \multicolumn{2}{|c|}{$\begin{array}{l}\text { PD-L1 expression } \\
\text { by population }\end{array}$} & \multirow[t]{2}{*}{$\begin{array}{l}\text { Statistical } \\
\text { value }\end{array}$} & \multirow[t]{2}{*}{$\begin{array}{l}\text { Prevalence } \\
\text { ratio }(\mathrm{CI})\end{array}$} & \multirow[t]{2}{*}{$\begin{array}{l}\text { Further } \\
\text { comments }\end{array}$} \\
\hline & $\mathrm{EBV}+$ & EBV- & & & \\
\hline $\begin{array}{l}\text { Kinch, } \\
2019 \text { (26) }\end{array}$ & mPD-L1: 0 & mPD-L1: 0 & N/A & N/A & $\begin{array}{l}\text { "In PD-L1 negative } \\
\text { cases, the } \\
\text { microenvironment } \\
\text { of the tumor was } \\
\text { assessed for an } \\
\text { expression of PD-L1 } \\
\text { exceeding } 20 \% \text { of } \\
\text { the cells [...] but } \\
\text { this was not observed" } \\
\text { "there was no } \\
\text { association between } \\
\text { expression of } \\
\text { intratumoral Tregs and } \\
\text { PD-1 or its ligands" }\end{array}$ \\
\hline $\begin{array}{l}\text { Veloza, } \\
2019 \text { (27) }\end{array}$ & tPD-L1+: 20/21 (95\%) & tPD-L1+: 8/16 (50\%) & N/A & $\begin{array}{l}\text { tPD-L1+: } 1.90 \\
(1.16,3.14)\end{array}$ & N/A \\
\hline $\begin{array}{l}\text { Ishikawa, } \\
\text { 2018a (28) }\end{array}$ & mPD-L1+: 12/14 (86\%) & mPD-L1+: 17/40 (43\%) & $\begin{array}{c}\text { mPD-L1 } \\
p \text {-value: } 0.006\end{array}$ & $\begin{array}{c}\text { mPD-L1+: } 2.02 \\
\quad(1.33,3.07)\end{array}$ & $\begin{array}{l}\text { "Histological results } \\
\text { showed that PD-L1 } \\
\text { was detected in } \\
\text { microenvironmental } \\
\text { immune cells at a } \\
\text { significantly } \\
\text { higher rate" } \\
\text { "Patients with } \\
\text { EBV+ gDLBCL } \\
\text { commonly exhibited } \\
\text { microenvironmental } \\
\text { PD-L1 expression } \\
\text { and showed a } \\
\text { significantly worse } \\
\text { prognosis than } \\
\text { subjects with } \\
\text { EBV- gDLBCL" }\end{array}$ \\
\hline $\begin{array}{l}\text { Ishikawa, } \\
\text { 2018b (29) }\end{array}$ & mPD-L1: 8/8 (100\%) & mPD-L1: $31 / 48$ (65\%) & $\begin{array}{c}\text { mPD-L1 } \\
p \text {-value: } 0.09\end{array}$ & $\begin{array}{c}\text { mPD-L1+: } 1.55 \\
\quad(1.26,1.90)\end{array}$ & N/A \\
\hline $\begin{array}{l}\text { Kiyasu, } \\
2015 \text { (30) }\end{array}$ & mPD-L1+:30/76 (55.6\%) & mPD-L1+: 124/994 (12.5\%) & N/A & $\begin{array}{c}\text { mPD-L1+: } 3.16 \\
(2.29,4.37)\end{array}$ & N/A \\
\hline
\end{tabular}

tPD-L1+: Tumor associated macrophage positivity; mPD-L1+: microenvironment positivity; N/A: not applicable.

Two articles $(22,23)$ utilised a modified score based on expression values, where IHC score (23) showed higher detection in EBV+ cases with a statically significant value. The other papers $(22)$ identified PR 1.45 (1.05, 2.02) for $\mathrm{EBV}+$ irrespective of the staining score, where EBV latency had higher \%PD-L1+ expression and higher staining intensity in EBNA2+ cases, p-values: 0.0125 and 0.004, respectively. Using flow cytometry, another study (31) stated that PD-L1+ expression was higher in EBV+ cases, PR 1.78 $(0.88,3.64)$, but specified EBV and cell of origin as separate factors.
Tumour microenvironment. Five papers examined PD-L1 expression in relation to the tumour microenvironment (2630 ) and four (27-30) found an EBV association with PR $>1$, whilst one paper (31) identified no PD-L1 positive cases in the microenvironment of either subgroup (Table III).

All papers adopted a $20 \%$ threshold for positivity. Of those, four analysed total tissue cellularity $(26,28-30)$, where two which did not specify the cellularity further found an association in EBV+ cases, at $p$-values of 0.09 (29) and 0.006 (28), respectively. One paper further specified the total tissue cellularity to non-malignant cells only (30), finding PR 3.16 
Table IV. Cell of origin commentary, cell type comparison and relation to PD-L1 expression in nine included studies.

\begin{tabular}{|c|c|c|c|c|c|c|c|}
\hline \multirow[t]{3}{*}{$\begin{array}{l}\text { First author, } \\
\text { Year of publication }\end{array}$} & \multirow[t]{3}{*}{$\begin{array}{l}\text { Cell type } \\
\text { commentary }\end{array}$} & \multicolumn{4}{|c|}{$\begin{array}{l}\text { Cell of } \\
\text { origin type }\end{array}$} & \multicolumn{2}{|c|}{$\begin{array}{l}\text { PD-L1 expression } \\
\text { relating to EBV+ }\end{array}$} \\
\hline & & \multicolumn{2}{|c|}{ GCB } & \multicolumn{2}{|c|}{ N-GCB } & & \\
\hline & & $\mathrm{EBV}+$ & EBV- & $\mathrm{EBV}+$ & EBV- & & \\
\hline \multirow{2}{*}{$\begin{array}{l}\text { Anastasiadou, } \\
2019(22)\end{array}$} & \multirow[b]{2}{*}{$\begin{array}{l}\text { "suggest that EBV+ } \\
\text { non-GC DLBCLs } \\
\text { have slightly higher } \\
\text { PD-L1 expression than } \\
\text { those non-GC DLBCLs } \\
\text { without the virus." } \\
\text { "number of cells } \\
\text { with high staining } \\
\text { intensity }(+2,+3) \\
\text { [...] was significantly } \\
\text { higher in EBNA2+ } \\
\text { ABC DLBCLs in } \\
\text { comparison with } \\
\text { EBNA2- cases" }\end{array}$} & \multirow[t]{2}{*}{$0(0 \%)$} & \multirow[t]{2}{*}{$10(63 \%)$} & \multirow[t]{2}{*}{$11(100 \%)$} & \multirow[t]{2}{*}{$6(37 \%)$} & \multicolumn{2}{|c|}{ PR PD-L1+: $1.45(1.05,2.02)$} \\
\hline & & & & & & $\begin{array}{c}\text { N-GCB } \\
\text { quantitative } \\
\text { analysis: } \\
\% \text { PD-L1+ cells: } \\
\text { 91.8 (78-100); } \\
\text { where EBNA2+ } \\
\text { latency III=99.3\% } \\
\text { and EBNA2- latency } \\
\text { II }=84.3 \% \text {; } \\
\text { EBNA2+/EBNA2- } \\
p \text {-value=0.0125 } \\
\% \text { of strong } \\
\text { intensity score }(2-3) \text { : } \\
\text { 45.3\% (where } \\
\text { EBNA2+latency } \\
\text { III=70\%,EBNA2- } \\
\text { latency II=20.7\%); } \\
\text { EBNA2+/EBNA2- } \\
p \text {-value=0.0040 }\end{array}$ & $\begin{array}{l}\text { N-GCB } \\
\text { quantitative } \\
\text { analysis: } \\
\text { \% PD-L1+ cells: } \\
28(19-35)\end{array}$ \\
\hline Jiang, 2019 (23) & N/A & $3(10 \%)$ & $39(47 \%)$ & $27(90 \%)$ & $44(53 \%)$ & \multicolumn{2}{|c|}{$p$-value: 0.006} \\
\hline Keane, 2019 (25) & N/A & $16(69 \%)$ & $174(61 \%)$ & $7(31 \%)$ & $80(48 \%)$ & \multicolumn{2}{|c|}{ Gene count $p$-value $<0.0001$} \\
\hline Kinch, 2019 (26) & N/A & $1(4 \%)$ & $8(40 \%)$ & $25(96 \%)$ & $11(55 \%)$ & \multicolumn{2}{|c|}{$\begin{array}{c}\text { PR PD-L1+: } 1.63(0.89,2.99) \\
\text { mPD-L1+: N/A }\end{array}$} \\
\hline Veloza, 2019 (27) & $\begin{array}{l}\text { "EBV-positive } \\
\text { DLBCL cases were more } \\
\text { commonly non-GCB } \\
\text { than GCB }(94 \% \\
\text { versus } 6 \%, p=0.001) "\end{array}$ & $1(5 \%)$ & $9(56 \%)$ & $17(81 \%)$ & $5(31 \%)$ & \multicolumn{2}{|c|}{$\begin{array}{l}\text { PR PD-L1+: } 2.29(1.19,4.41) \\
\text { PR tPD-L1+: } 1.90(1.16,3.14)\end{array}$} \\
\hline $\begin{array}{l}\text { Ishikawa, } \\
\text { 2018a (28) }\end{array}$ & N/A & $8(33 \%)$ & $79(37 \%)$ & $16(67 \%)$ & $129(62 \%)$ & \multirow{2}{*}{\multicolumn{2}{|c|}{$\begin{array}{c}\text { PR PD-L1+: N/A } \\
\text { PR mPD-L1: } 2.02(1.33,3.07) \\
\text { PR PD-L1+: } 9.8(0.98,97.96) \\
\text { PR mPD-L1: } 1.55(1.26,1.90)\end{array}$}} \\
\hline $\begin{array}{l}\text { Ishikawa, } \\
\text { 2018b (29) }\end{array}$ & $\begin{array}{l}\text { "Most of our cases } \\
(90 \%) \text { of EBV+ } \\
\text { iDLBCL had non-GCB } \\
\text { immunophenotype, } \\
\text { which may be related to } \\
\text { their adverse outcome" }\end{array}$ & $1(10 \%)$ & $21(42 \%)$ & $9(90 \%)$ & $29(58 \%)$ & & \\
\hline $\begin{array}{l}\text { Quan, } \\
2015(31)\end{array}$ & $\begin{array}{c}\text { "PD-L1 expression in } \\
\text { DLBCL occurs almost } \\
\text { exclusively in tumors of } \\
\text { non-germinal center origin } \\
\text { and EBV positive DLBCL." }\end{array}$ & Not reported & $8(40 \%)$ & Not reported & $12(60 \%)$ & \multicolumn{2}{|c|}{$\begin{array}{l}\text { Combined (GCB, n-GCB) } \\
\text { PD-L1+: } 1.78(0.88,3.64)\end{array}$} \\
\hline $\begin{array}{l}\text { Yoon, } \\
2015 \text { (32) }\end{array}$ & N/A & $0(0 \%)$ & $0(0 \%)$ & $13(100 \%)$ & $23(100 \%)$ & \multicolumn{2}{|c|}{$\begin{array}{l}\text { 9q24.1 copy number gain: } \\
38.5 \% \text { vs. } 24 \% \text { EBV- }\end{array}$} \\
\hline
\end{tabular}

N/A: Not applicable.

$(2.29,4.37)$ for EBV+ cases. This article considered samples which were already established as PD-L1- in tumour cells, an approach also undertaken by another study (26). However, the latter identified no patients with PD-L1 positivity, and also commented on the lack of association between PD-L1 and intratumoural regulatory T-cells irrespective of the EBV status.

One paper (30) remarked on a significantly higher rate of PD-L1 detection in microenvironmental immune cells 
Barzyk and Sheriff: EBV Positivity and PD-L1 Expression in DLBCL (Review)

Table V. Frequency of genetic aberrations relevant to PD-L1 expression in EBV+ and EBV-cases in four included studies.

\begin{tabular}{|c|c|c|c|c|c|}
\hline \multirow[t]{2}{*}{$\begin{array}{l}\text { First author, } \\
\text { Year of publication }\end{array}$} & \multicolumn{2}{|c|}{$\begin{array}{l}\text { PD-L1 expression } \\
\text { by population }\end{array}$} & \multirow[t]{2}{*}{$\begin{array}{l}\text { Statistical } \\
\text { value }\end{array}$} & \multirow[t]{2}{*}{$\begin{array}{l}\text { Prevalence } \\
\text { ratio }(\mathrm{CI})\end{array}$} & \multirow[t]{2}{*}{$\begin{array}{l}\text { Further } \\
\text { comments }\end{array}$} \\
\hline & $\mathrm{EBV}+$ & EBV- & & & \\
\hline $\begin{array}{l}\text { Kataoka, } \\
2019(24)\end{array}$ & $\begin{array}{l}\text { PD-L1/L2 } \\
\text { Genetic aberrations } \\
\text { frequency: } 5 / 27\end{array}$ & $\begin{array}{c}\text { PD-L1/L2 } \\
\text { Genetic aberrations } \\
\text { frequency: } 1 / 48\end{array}$ & $\begin{array}{l}p \text {-value: }<0.05 \text {. } \\
\text { 'The observation was } \\
\text { confirmed by examining } \\
\text { DLBCL cases in the } \\
\text { TCGA cohort }(27 \% v s \text {. } \\
5 \%, p=0.07) \text { ' }\end{array}$ & $\begin{array}{c}\text { Genetic } \\
\text { aberration } \\
8.9 \\
(1.09,72.20)\end{array}$ & $\begin{array}{l}\text { "Although the numbers of mutations } \\
\text { and CNAs were comparable } \\
\text { between EBV- and + DLBCLs, } \\
\text { EBV+ DLBCLs had a larger number } \\
\text { of SVs than EBV- tumors', targeted } \\
\text { sequencing } p \text {-value }<0.05, \\
\text { RNA-sequencing + SNP array } \\
\text { (TCGA) } p \text {-value=0.07" } \\
\text { "There were no differences in } \\
\text { genetic alterations between } \\
\text { EBV+ DLBCLs with and } \\
\text { without PD-L1/PD-L2 } \\
\text { genetic alterations" }\end{array}$ \\
\hline $\begin{array}{l}\text { Keane, } \\
2019(25)\end{array}$ & $\begin{array}{c}\text { Gene count: } \\
364(31-760)^{*} \\
\text { *Values interpreted } \\
\text { from graph }\end{array}$ & $\begin{array}{c}\text { Gene count: } \\
82(4-1536)^{*} \\
\text { *Values interpreted } \\
\text { from graph }\end{array}$ & $p$-value $<0.0001$ & $\mathrm{~N} / \mathrm{A}$ & $\begin{array}{l}\text { "LMP1, an EBV-related oncogene } \\
\text { with immunomodulatory properties, } \\
\text { showed significant correlations } \\
\text { with PD-L1 }(\mathrm{r}=0.49, p=0.014) . "\end{array}$ \\
\hline $\begin{array}{l}\text { Veloza, } \\
2019 \text { (27) }\end{array}$ & $\begin{array}{l}\text { PD-L1 CNA: } \\
10 / 13(77 \%)\end{array}$ & $\begin{array}{l}\text { PD-L1 CNA: } \\
8 / 12(67 \%)\end{array}$ & $\begin{array}{l}\text { 'CNAs in a variable } \\
\text { proportion of cells, } \\
\text { regardless of EBV } \\
\text { status }(p=0.6) \text { ' }\end{array}$ & $\mathrm{N} / \mathrm{A}$ & $\begin{array}{l}\text { FISH: "Moreover, the number of } \\
\text { cells with PD-L1 CNAs did not } \\
\text { differ between EBV-positive and E } \\
\text { BV-negative cases [residual PD-L1 } \\
\text { disomies: } 76 \pm \text { standard deviation } \\
\text { (SD) } 16 \text { versus } 87 \pm \text { SD 14, } \\
\text { respectively, } p=0.1 \text { ].", } \\
\text { "high percentages of residual PD-L1 } \\
\text { disomies were observed in most cases } \\
\text { suggests that EBV may play a major } \\
\text { role in PD-L1 up-regulation in PTLD, } \\
\text { whereas PD-L1 CNAs may further } \\
\text { increase PD-L1 expression in } \\
\text { variable numbers of neoplastic } \\
\text { cells in EBV+ cases" } \\
\text { "most EBV- DLBCL cases with } \\
\text { PD-L1+ TCs showed frequent } \\
\text { PD-L1 CNAs, which indicates } \\
\text { that genetic alterations in the } \\
\text { 9p24.1 locus may have an } \\
\text { important role in modulating } \\
\text { PD-L1 expression in some EBV- } \\
\text { PTLD cases. However, EBV- } \\
\text { PD-L1+ TCs without PD-L1 } \\
\text { CNAs were also found, which } \\
\text { suggests that additional pathways } \\
\text { of activation could be involved." }\end{array}$ \\
\hline $\begin{array}{l}\text { Yoon, } \\
2015(32)\end{array}$ & $\begin{array}{c}\text { 9q24.1 copy } \\
\text { number gain: } 38.5 \%\end{array}$ & $\begin{array}{l}\text { 9q24.1 copy } \\
\text { number } \\
\text { gain: } 25 \%\end{array}$ & & N/A & $\begin{array}{l}\text { "The overall frequency of genomic } \\
\text { alterations was lower in EBV+DLBCL } \\
\text { than it was in EBV-DLBCL. }\end{array}$ \\
\hline & $\begin{array}{l}\text { PDCD1LG2 gene } \\
\text { overexpression noted } \\
\text { in EBV+: } 24.47 \% \\
\text { PDCD1LG2 } \\
\text { enrichment score } \\
\text { identified at } 3.74\end{array}$ & & $\begin{array}{l}p \text {-value }<0.001 \\
\text { FDR }<0.001 \\
p \text {-value: } 0.003 \\
\text { FDR: } 3.86 \%\end{array}$ & & $\begin{array}{l}\text { Thirteen recurrent copy number } \\
\text { aberrations }(>30 \%) \text { were observed } \\
\text { in EBV+DLBCL, whereas } \\
\text { EBV-DLBCL showed } 24 \\
\text { chromosomal regions with } \\
\text { recurrent aberrations." }\end{array}$ \\
\hline
\end{tabular}

N/A: Not applicable. 
without further evidence. Another study (27) examined this in relation to tumour associated macrophages (TAM), noting an EBV+ related increase in PD-L1+ at PR 1.90 (1.16, 3.14).

Cell of origin subtype. Overall, nine studies characterised cell of origin (22-23, 25-29, 31, 32) (Table IV). Six papers (22-23, 26-29) noted EBV+ N-GCB majority, one study found N-GCB was higher in EBV- cases (25), one did not identify any cases with GCB origin (32), and one did not report $\mathrm{EBV}+$ cell origin (31). Five papers reported origin without further analysis $(23,25-26,28,32)$ and among those, three reported $\geq 90 \%$ of $\mathrm{N}-\mathrm{GCB}$ in $\mathrm{EBV}+$ cases $(23,26,32)$, whilst another had a $67 \%$ majority (28). There was only one study where N-GCB was a minority at $31 \%$ (25).

In four papers reporting origin in detail $(22,27,29,31)$, two found that EBV+ DLBCL cases were more commonly $\mathrm{N}-\mathrm{GCB}$, at $94 \%$ with $p=0.001$ (27) and $90 \%$, respectively (29). EBV+ cases were exclusively N-GCB in one study (22), showing increased PD-L1+ cells (91\% vs. 28\%). The fourth paper (31) reported that PD-L1 expression appeared more commonly in $\mathrm{N}-\mathrm{GCB}$ subtype and $\mathrm{EBV}+$ cases, but $\mathrm{EBV}+$ cell of origin was not reported. When the overall cell origin proportions were combined, $\mathrm{EBV}+$ cases were 0.19:0.81 GCB:N-GCB, while EBV- cases were 0.5:0.5 GCB:N-GCB.

In relation to $\mathrm{PD}-\mathrm{L1}$, five papers $(22-23,26-27,29)$ reported an increase in PD-L1 in tumour cell when EBV+ $\mathrm{N}-\mathrm{GCB}$ cases were greater in number, although two of those included $P R=1(26,29)$. One of the two papers (29) showed $\mathrm{PR}>1$ increase in environment, consistent with two other papers reporting on microenvironment and cell type $(27,28)$.

EBV status and PD-L1 genetic aberrations. Four studies (24$25,27,32$ ) examined genetic aberrations relating to PD-L1 and 9q24.1 (Table V). All studies noted an increase, but only two concluded that EBV+ harbours significant change (24, 25). One paper (25) showed an EBV-related increase in frequency of PD-L1 gene count, where latent membrane protein 1 (LMP1) showed significant correlations. Another paper (24) described an increase in frequency of PD-L1/PDL2 structural variation (SV) in EBV+ cases, although SV type was not specified. Interestingly, it noted that EBV+ cases did not show differences in other genetic aberrations irrespective of the PD-L1/PD-L2 alteration, while another study (32) stated that other genetic aberrations where lower in $\mathrm{EBV}+$ cases.

In contrast, despite noting that PD-L1 copy number alterations (CNAs) were detected in more EBV+ cases, another study (27) found PD-L1 CNAs in variable proportion of cells regardless of EBV status. In addition, no significant difference was found between disomies of EBV+/- cases, although it was noted that with high percentage of residual disomies, EBV may play a role in PD-L1 up-regulation in post-transplant lymphoproliferative disorder (PTLD). One study (32) found a 9q24.1 copy number gain in EBV+, where it was reported that the PD-L2 gene (PDCD1LG2) located on 9q24.1 was also overexpressed in EBV+ cases.

\section{Discussion}

The systematic review included eleven cross-sectional studies and to the authors' knowledge, this was the first systematic review which aimed to determine whether EBV impacts PD-L1 expression in DLBCL tumour biopsy. There was considerable variability in the methodologies of published literature and although staining thresholds seemed more consistent, it is apparent that investigation of PD-L1 expression requires a degree of standardisation to distinguish definite DLBCL trends. However, the review was able to identify several research avenues to explore.

$\mathrm{EBV}+$ is unlikely to have an impact on PD-L1+ in tumour cells as despite seven out of eight papers finding an apparent increase $(22-23,27-29,31,32)$, PR overlap at 95\% CI was noted. Particularly in cases where 5\% threshold was applied giving commonality to results (26-29), values indicated that there may be no difference as some PR $>1$ had CI close to 1.0. Importantly, as this is an arbitrary cut-off value where higher thresholds may show definite trends (34), and as EBV-related PD-L1 expression has been identified in epithelial malignancies (35), this result should not be negated, and should be further investigated using higher positivity thresholds. Due to small sample sizes for EBV+ cohorts, it is likely that patients experience PD-L1 related changes, however, this does not appear to be an exclusive feature of $\mathrm{EBV}+$ patients. As such, there is a need to identify the non-EBV mechanism of this phenomenon, although EBV latency may be a contributing factor in disease progression.

One of the most interesting trends indicated that $\mathrm{EBV}+$ is associated with increased PD-L1 expression in tumour microenvironment. Although taken with caution due to limited number of studies, the PR values suggest that this may be a common finding (36). However, as the $20 \%$ threshold was applied to various parameters of the total tissue cellularity, it is possible that this result arose due to selection or confirmation bias (34). Moreover, the use of different antibodies and dilution factors could account for the observed patterns due to false-positives as selected dilutions were not justified (37). Taking into consideration that EBV relationship to PD-L1 in tumour cell is unlikely, it is apparent that selected patients might benefit from targeted anti-PD-1 therapies as the $20 \%$ threshold relating PD-L1 to tumour microenvironment appears to show a more predominant EBV link to PD-L1 expression. However, as this feature is not solely found in $\mathrm{EBV}+$ patients, this finding further supports the notion that a non-EBV related mechanism operates leading to PD-L1 increase. 
It is well understood that N-GCB DLBCL is associated with worse outcomes (38). A pattern regarding PD-L1 increase in N-GCB was found across several studies (39) suggesting that those of N-GCB cell type may benefit from introduction of PD-L1 therapy irrespective of EBV status. However, EBV has been linked to increased pSTAT3 expression in N-GCB (40), highlighting that this behaviour is likely cell-type dependant, where EBV+ may have an enhancing effect on PD-L1. EBV has been stipulated to up-regulate PD-L1 via a direct effect on JUN-B signalling cascade via LMP-1 (41-43) or via indirect up-regulation of inflammatory cytokines (44-46), with effects on JAK/STAT signalling pathway in Hodgkin and NHL (47). As five articles in this review related N-GCB to an increase in PD-L1 expression (22-23, 26-27, 29), although with variable $\mathrm{PR}$, this result indicates that $\mathrm{EBV}+$ patients may have greater likelihood of PD-L1+ and may need treatment revaluation. This includes possible addition of anti-PD-L1 medication such as Pembrolizumab (48) to selected patients considering that various trials involving R-CHOP combinations have not yielded positive effects (49). The analysis of cell type with focus on N-GCB and its impact on PD-L1 should thus be prioritised in future research to enable appropriate immunotherapeutic strategy and risk stratification in DLBCL. Moreover, more studies should utilise genetic approaches in addition to methods such as IHC, thus enabling the assessment of whether PD-L1+ and EBV+ are independent prognostic factors considering the direct and indirect involvement of EBV, particularly in relation to $\mathrm{N}-\mathrm{GCB}$ potency and worse prognostic outcomes. Regarding patient characteristics, it has been reassuring to see inclusion of younger patients following the WHO classification update, where aside from $\mathrm{N}-\mathrm{GCB}$, no other correlations were identified.

Considering genetic aberrations, findings similar to those identified in this review were noted in PTLD-DLBCL (50). However, due to mixed methods and commentary, no consensus can be appreciated despite PD-L1 aberrations appearing to increase in EBV+. Various studies link 9p24.1 locus alteration $(43,47,51)$ and the JAK/STAT pathway (42, 52) as a contributing factor to PD-L1 overexpression irrespective of the EBV status, as identified in this review. This supports the notion that EBV is not a sole deterministic factor (53), but likely an enhancer of PD-L1. As such, it is important to determine the level of contribution of EBV to PD-L1 genetic aberrations and JAK/STAT through the indirect mechanisms. Of note, $\mathrm{EBV}+$ may also explain the relatively small gain of genetic aberrations identified in DLBCL in some studies (54), as often EBV status is not addressed and such cases may in fact be EBV+, affecting PD-L1 expression via the direct pathway.

Limitations. The review included a comprehensive search of literature, where stringent inclusion criteria ensured that studies which described relevant methodology in sufficient detail were included in the synthesis. However, a substantial amount of literature did not describe methodology to sufficient standard and multiple results were presented in conference abstracts. As these articles were not suitable for inclusion in this review and only English language papers were included, publication bias may have been introduced. Importantly, EBER status was considered sufficient for EBV identification irrespective of threshold, however experts agree that $>50 \%$ of malignant cells should be EBER positive (55) and this could have impacted the data. Similarly, thresholds for PD-L1+ and mPD-L1+ need standardisation, as overall meta-analysis was not possible due to diversity of PD-L1 and EBV measures. Despite application of PR and CI to provide commonality to data comparison, variability in thresholds meant that overall, the predictive capability of this parameter was less reliable.

It is important to note that gene expression does not equate to molecular expression and studies where staining was not used to clarify results offer limited picture into impact of a genetic aberration. Furthermore, due to relative rarity of EBV+ DLBCL, sample sizes were not justified in multiple studies and this could have caused data inaccuracies.

Implications for future research. One of the most important factors identified from this review is the need to standardise reporting and thresholds, perhaps at higher levels (34), to enable meta-analysis of identified trends. More studies should utilise a dual approach with staining and genetics to clarify whether EBV-related changes affect PD-L1 expression and this must be related to cell of origin type, which appears to be more indicative of PD-L1 relationship.

\section{Conclusion}

With increased number of EBV+ cases identified as N-GCB, this systematic review indicates that cell of origin is of relevance to DLBCL, where a link or enhancement of PDL1 pathway via EBV may be of significance. EBV+ does not seem to be the sole factor determining PD-L1+ despite noting increase in PD-L1 in tumour microenvironment as EBV- patients also show PD-L1+, and it is likely that another mechanism is involved. Although this needs to be further explored due to small sample size, it is apparent that the protocols require standardisation to confirm trends through large-scale studies before any anti-PD-L1 treatment application is considered.

\section{Conflicts of Interest}

The Authors declare no potential conflicts of interest. The review has no funding source. 


\section{Authors' Contributions}

GA Barzyk (study concept and design, data collection, data analysis and interpretation, manuscript preparation and final approval), $\mathrm{V}$ Sheriff (study design, data collection, data analysis and interpretation, manuscript preparation and final approval).

\section{References}

1 Wild CP, Weiderpass E and Stewart BW: Non-Hodgkin lymphoma. In: World Cancer Report: Cancer Research for Cancer Prevention. Lyon, France: International Agency for Research on Cancer, pp. 468-477, 2020.

2 Li Y, Wang Y, Wang Z, Yi D and Ma S: Racial differences in three major NHL subtypes: Descriptive epidemiology. Cancer Epidemiol 39(1): 8-13, 2015. PMID: 25560974. DOI: 10.1016/ j.canep.2014.12.001

3 Sukswai N, Lyapichev K, Khoury JD and Medeiros LJ: Diffuse large B-cell lymphoma variants: an update. Pathology 52(1): 53-67, 2020. PMID: 31735345. DOI: 10.1016/j.pathol. 2019.08.013

4 Shi Y, Han Y, Yang J, Liu P, He X, Zhang C, Zhou S, Zhou L, Qin Y, Song Y, Liu Y, Wang S, Jin J, Gui L and Sun Y: Clinical features and outcomes of diffuse large B-cell lymphoma based on nodal or extranodal primary sites of origin: Analysis of 1,085 WHO classified cases in a single institution in China. Chin J Cancer Res 31(1): 152-161, 2019. PMID: 30996573. DOI: 10.21147/j.issn.1000-9604.2019.01.10

5 Liu Y and Barta SK: Diffuse large B-cell lymphoma: 2019 update on diagnosis, risk stratification, and treatment. Am J Hematol 94(5): 604-616, 2019. PMID: 30859597. DOI: 10.1002/ajh.25460

6 Lenz G: Insights into the molecular pathogenesis of activated Bcell-like diffuse large B-Cell lymphoma and its therapeutic implications. Cancers 7(2): 811-822, 2015. PMID: 26010601. DOI: $10.3390 /$ cancers 7020812

7 Li S, Young KH and Medeiros LJ: Diffuse large B-cell lymphoma. Pathology 50(1): 74-87, 2018. PMID: 29167021. DOI: 10.1016/ j.pathol.2017.09.006

8 Castillo JJ, Beltran BE, Miranda RN, Young KH, Chavez JC and Sotomayor EM: EBV-positive diffuse large B-cell lymphoma, not otherwise specified: 2018 update on diagnosis, risk-stratification and management. Am J Hematol 93(7): 953-962, 2018. PMID: 29984868. DOI: 10.1002/ajh.25112

9 Swerdlow SH, Campo E, Pileri SA, Harris NL, Stein H, Siebert R, Advani R, Ghielmini M, Salles GA, Zelenetz AD and Jaffe ES: The 2016 revision of the World Health Organization classification of lymphoid neoplasms. Blood 127(20): 2375-2390, 2016. PMID: 26980727. DOI: 10.1182/blood-2016-01-643569

10 Luzuriaga K and Sullivan JL: Infectious mononucleosis. N Engl J Med 362(21): 1993-2000, 2010. PMID: 20505178. DOI: 10.1056/NEJMcp1001116

11 Saha A and Robertson ES: Mechanisms of B-Cell oncogenesis induced by Epstein-Barr Virus. J Virol 93(13): e00238-19, 2019. PMID: 30971472. DOI: 10.1128/JVI.00238-19

12 Castillo JJ, Beltran BE, Miranda RN, Young KH, Chavez JC and Sotomayor EM: EBV-positive diffuse large B-cell lymphoma of the elderly: 2016 update on diagnosis, risk-stratification, and management. Am J Hematol 91(5): 529-537, 2016. PMID: 27093913. DOI: $10.1002 /$ ajh. 24370
13 Zhou Y, Xu Z, Lin W, Duan Y, Lu C, Liu W, Su W, Yan Y, Liu H, Liu L, Zhong M, Zhou J and Zhu H: Comprehensive genomic profiling of EBV-positive diffuse Large B-cell lymphoma and the expression and clinicopathological correlations of some related genes. Front Oncol 9: 683, 2019. PMID: 31403034. DOI: 10.3389/fonc. 2019.00683

14 Rezk SA, Zhao X and Weiss LM: Epstein-Barr virus (EBV)associated lymphoid proliferations, a 2018 update. Hum Pathol 79: 18-41, 2018. PMID: 29885408. DOI: 10.1016/j.humpath. 2018.05.020

15 Syn NL, Teng MWL, Mok TSK and Soo RA: De-novo and acquired resistance to immune checkpoint targeting. Lancet Oncol 18(12): e731-e741, 2017. PMID: 29208439. DOI: 10.1016/S14702045(17)30607-1

16 Kanakry JA and Ambinder RF: EBV-related lymphomas: new approaches to treatment. Curr Treat Options Oncol 14(2): 224236, 2013. PMID: 23549980. DOI: 10.1007/s11864-013-0231-y

17 Song M, Park B and Uhm J: Understanding immune evasion and therapeutic targeting associated with PD-1/PD-L1 pathway in diffuse large B-cell lymphoma. Int J Mol Sci 20(6): 1326, 2019. PMID: 30884772. DOI: 10.3390/ijms20061326

18 Cohen M, Vistarop AG, Huaman F, Narbaitz M, Metrebian F, De Matteo E, Preciado MV and Chabay PA: Epstein-Barr virus lytic cycle involvement in diffuse large B cell lymphoma. Hematol Oncol 36(1): 98-103, 2017. PMID: 28707331. DOI: 10.1002/hon. 2465

19 Brown P, Brunnhuber K, Chalkidou K, Chalmers I, Clarke M, Fenton M, Forbes C, Glanville J, Hicks N, Moody J, Twaddle S, Timimi $\mathrm{H}$ and Young $\mathrm{P}$ : How to formulate research recommendations. BMJ 333(7572): 804-806, 2006. PMID: 17038740. DOI: $10.1136 / \mathrm{bmj} .38987 .492014 .94$

20 Moher D, Liberati A, Tetzlaff J and Altman D: Preferred reporting items for systematic reviews and meta-analyses: the PRISMA statement. PLoS Med 6(7): e1000097, 2009. PMID: 19621072. DOI: 10.1371/journal.pmed.1000097

21 Downes MJ, Brennan ML, Williams HC and Dean RS: Development of a critical appraisal tool to assess the quality of cross-sectional studies (AXIS). BMJ Open 6(12): e011458, 2016. PMID: 27932337. DOI: 10.1136/bmjopen-2016-011458

22 Anastasiadou E, Stroopinsky D, Alimperti S, Jiao AL, Pyzer AR, Cippitelli C, Pepe G, Severa M, Rosenblatt J, Etna MP, Rieger S, Kempkes B, Coccia EM, Ho Sui SJ, Chen CS, Uccini S, Avigan D, Faggioni A, Trivedi P and Slack FJ: Epstein-Barr virusencoded EBNA2 alters immune checkpoint PD-L1 expression by downregulating miR-34a in B-cell lymphomas. Leukemia 33(1): 132-147, 2019. PMID: 29946193. DOI: 10.1038/s41375-0180178-X

23 Jiang X, Yu B, Yan W, Lee J, Zhou X and Li X: Epstein-Barr virus-positive diffuse large B-cell lymphoma features disrupted antigen capture/presentation and hijacked T-cell suppression. Oncoimmunology 9(1): 1683346, 2019. PMID: 32002294. DOI: $10.1080 / 2162402 X .2019 .1683346$

24 Kataoka K, Miyoshi H, Sakata S, Dobashi A, Couronné L, Kogure Y, Sato Y, Nishida K, Gion Y, Shiraishi Y, Tanaka H, Chiba K, Watatani Y, Kakiuchi N, Shiozawa Y, Yoshizato T, Yoshida K, Makishima H, Sanada M, Onozawa M, Teshima T, Yoshiki Y, Ishida T, Suzuki K, Shimada K, Tomita A, Kato M, Ota Y, Izutsu K, Demachi-Okamura A, Akatsuka Y, Miyano S, Yoshino T, Gaulard P, Hermine O, Takeuchi K, Ohshima K and Ogawa S: Frequent structural variations involving programmed death ligands 
in Epstein-Barr virus-associated lymphomas. Leukemia 33(7): 1687-1699, 2019. PMID: 30683910. DOI: 10.1038/s41375-0190380-5

25 Keane C, Tobin J, Gunawardana J, Francis S, Gifford G, Gabrielli S, Gill A, Stevenson W, Talaulikar D, Gould C, Jain S, Birch S, Hertzberg $\mathrm{M}$ and Gandhi MK: The tumour microenvironment is immuno-tolerogenic and a principal determinant of patient outcome in EBV-positive diffuse large B-cell lymphoma. Eur J Haematol 103(3): 200-207, 2019. PMID: 31211907. DOI: 10.1111/ejh.13274

26 Kinch A, Sundström C, Baecklund E, Backlin C, Molin D and Enblad G: Expression of PD-1, PD-L1, and PD-L2 in posttransplant lymphoproliferative disorder after solid organ transplantation. Leuk Lymphoma 60(2): 376-384, 2019. PMID: 30033844. DOI: 10.1080/10428194.2018.1480767

27 Veloza L, Teixido C., Castrejon N, Climent F, Carrió A, Marginet M, Soldini D, González-Farré B, Ribera-Cortada I, LopezGuillermo A, González-Barca E, Sierra A, Herrera M, Gómez C, Garcia A, Balagué O, Campo E and Martinez A: Clinicopathological evaluation of the programmed cell death 1 (PD1)/programmed cell death-ligand 1 (PD-L1) axis in post-transplant lymphoproliferative disorders: association with Epstein-Barr virus, PD-L1 copy number alterations, and outcome. Histopathology 75(6): 799-812, 2019. PMID: 30861172. DOI: 10.1111/his.13857

28 Ishikawa E, Tanaka T, Shimada K, Kohno K, Satou A, Eladl AE, Sakakibara A, Furukawa K, Funasaka K, Miyahara R, Nakamura M, Goto H, Nakamura S, Kato S and Hirooka Y: A prognostic model, including the EBV status of tumor cells, for primary gastric diffuse large B-cell lymphoma in the rituximab era. Cancer Med 7(7): 3510-3520, 2018. PMID: 29856127. DOI: 10.1002/ cam4.1595

29 Ishikawa E, Kato S, Shimada K, Tanaka T, Suzuki Y, Satou A, Kohno K, Sakakibara A, Yamamura T, Nakamura M, Miyahara R, Goto H, Nakamura S and Hirooka Y: Clinicopathological analysis of primary intestinal diffuse large B-cell lymphoma: Prognostic evaluation of CD5, PD-L1, and Epstein-Barr virus on tumor cells. Cancer Med 7(12): 6051-6063, 2018. PMID: 30449068. DOI: $10.1002 / \mathrm{cam} 4.1875$

30 Kiyasu J, Miyoshi H, Hirata A, Arakawa F, Ichikawa A, Niino D, Sugita Y, Yufu Y, Choi I, Abe Y, Uike N, Nagafuji K, Okamura T, Akashi K, Takayanagi R, Shiratsuchi M and Ohshima K: Expression of programmed cell death ligand 1 is associated with poor overall survival in patients with diffuse large B-cell lymphoma. Blood 126(19): 2193-2201, 2015. PMID: 26239088. DOI: 10.1182/blood-2015-02-629600

31 Quan L, Chen X, Liu A, Zhang Y, Guo X, Yan S, and Liu Y: PD1 Blockade can restore functions of T-Cells in Epstein-Barr viruspositive diffuse large B-cell lymphoma in vitro. PLoS One 10(9): e0136476, 2015. PMID: 26361042. DOI: 10.1371/journal. pone. 0136476

32 Yoon H, Park S, Ju H, Ha SY, Sohn I, Jo J, Do I, Min S, Kim SJ, Kim WS, Yoo HY and Ko YH: Integrated copy number and gene expression profiling analysis of Epstein-Barr virus-positive diffuse large B-cell lymphoma. Genes Chromosomes Cancer 54(6): 383-396, 2015. PMID: 25832818. DOI: 10.1002/gcc.22249

33 Tusher VG, Tibshirani R and Chu G: Significance analysis of microarrays applied to the ionizing radiation response. Proc Natl Acad Sci 98(9): 5116-5121, 2001. PMID: 11309499. DOI: 10.1073/pnas.091062498

34 Xing W, Dresser K, Zhang R, Evens AM, Yu H, Woda BA and Chen BJ: PD-L1 expression in EBV-negative diffuse large B-cell lymphoma: clinicopathologic features and prognostic implications. Oncotarget 7(37): 59976-59986, 2016. PMID: 27527850. DOI: 10.18632/oncotarget.11045

35 Nakayama A, Abe H, Kunita A, Saito R, Kanda T, Yamashita H, Seto Y, Ishikawa S and Fukayama M: Viral loads correlate with upregulation of PD-L1 and worse patient prognosis in EpsteinBarr Virus-associated gastric carcinoma. PLoS One 14(1): e0211358, 2019. PMID: 30695048. DOI: 10.1371/journal.pone. 0211358

36 Kwon D, Kim S, Kim P, Go H, Nam SJ, Paik JH, Kim YA, Kim TM, Heo DS, Kim CW and Jeon YK: Clinicopathological analysis of programmed cell death 1 and programmed cell death ligand 1 expression in the tumour microenvironments of diffuse large B cell lymphomas. Histopathology 68(7): 1079-1089, 2016. PMID: 26426431. DOI: 10.1111/his.12882

37 Kintsler S, Cassataro MA, Drosch M, Holenya P, Knuechel R and Braunschweig T: Expression of programmed death ligand (PD-L1) in different tumors. Comparison of several current available antibody clones and antibody profiling. Ann Diagn Pathol 41: 24-37, 2019. PMID: 31132649. DOI: 10.1016/j.anndiagpath.2019.05.005

38 Batlle-López A, de Villambrosía S, Francisco M, Malatxeberria S, Sáez A, Montalban C, Sánchez L, Garcia J, González-Barca E, López-Hernández A, Ruiz-Marcellan MC, Mollejo M, Grande C, Richards KL, Hsi ED, Tzankov A, Visco C, Xu-Monette ZY, Cao $\mathrm{X}$, Young KH, Piris MA, Conde E and Montes-Moreno S: Stratifying diffuse large B-cell lymphoma patients treated with chemoimmunotherapy: GCB/non-GCB by immunohistochemistry is still a robust and feasible marker. Oncotarget 7(14): 1803618049, 2016. PMID: 26910115. DOI: 10.18632/oncotarget.7495

39 Qiu L, Zheng $\mathrm{H}$ and Zhao $\mathrm{X}$ : The prognostic and clinicopathological significance of PD-L1 expression in patients with diffuse large B-cell lymphoma: a meta-analysis. BMC Cancer 19(1): 273, 2019. PMID: 30917792. DOI: 10.1186/ s12885-019-5466-y

40 Kwon HJ, Yang JM, Lee J, Lee JS and Paik JH: Clinicopathologic implication of PD-L1 and phosphorylated STAT3 expression in diffuse large B cell lymphoma. J Transl Med 16(1): 320, 2018. PMID: 30458835. DOI: 10.1186/s12967-018-1689-y

41 Teoh SH, Khoo JJ, Abdul Salam DSD, Peh SC and Cheah SCL: pSTAT3 and MYC in Epstein-Barr virus-positive diffuse large Bcell lymphoma. Malays J Pathol 41(3): 273-281, 2019. PMID: 31901912.

42 Chen BJ, Chapuy B, Ouyang J, Sun HH, Roemer MG, Xu ML, Yu H, Fletcher CD, Freeman GJ, Shipp MA and Rodig SJ: PDL1 expression is characteristic of a subset of aggressive B-cell lymphomas and virus-associated malignancies. Clin Cancer Res 19(13): 3462-3473, 2013. PMID: 23674495. DOI: 10.1158/10780432.CCR-13-0855

43 Green MR, Monti S, Rodig SJ, Juszczynski P, Currie T, O'Donnell E, Chapuy B, Takeyama K, Neuberg D, Golub TR, Kutok JL and Shipp MA: Integrative analysis reveals selective 9p24.1 amplification, increased PD-1 ligand expression, and further induction via JAK2 in nodular sclerosing Hodgkin lymphoma and primary mediastinal large B-cell lymphoma. Blood 116(17): 3268-3277, 2010. PMID: 20628145. DOI: 10.1182/ blood-2010-05-282780

44 Shen X, Zhang L, Li J, Li Y, Wang Y and Xu Z: Recent findings in the regulation of programmed death ligand 1 expression. Front Immunol 10: 1337, 2019. PMID: 31258527. DOI: 10.3389/fimmu. 2019.01337 
45 Sun C, Mezzadra R and Schumacher T: Regulation and function of the PD-L1 checkpoint. Immunity 48(3): 434-452, 2018. PMID: 29562194. DOI: 10.1016/j.immuni.2018.03.014

46 Choi JW, Kim Y, Lee JH and Kim YS: MYD88 expression and L265P mutation in diffuse large B-cell lymphoma. Hum Pathol 44(7): 1375-1381, 2013. PMID: 23380077. DOI: 10.1016/ j.humpath.2012.10.026

47 Gravelle P, Burroni B, Pericart S, Rossi C, Bezombes C, Tosolini M, Damotte D, Brousset P, Fournie JJ and Laurent C: Mechanisms of PD-1/PD-L1 expression and prognostic relevance in non-Hodgkin lymphoma: a summary of immunohistochemical studies. Oncotarget 8(27): 44960-44975, 2017. PMID: 28402953. DOI: $10.18632 /$ oncotarget.16680

48 Smith SD, Till BG, Shadman MS, Lynch RC, Cowan AJ, Wu QV, Voutsinas J, Rasmussen HA, Blue K, Ujjani CS, Shustov A, Cassaday RD, Fromm JR and Gopal AK: Pembrolizumab with R$\mathrm{CHOP}$ in previously untreated diffuse large B-cell lymphoma: potential for biomarker driven therapy. Br J Haematol 189(6): 1119-1126, 2020. PMID: 32030732. DOI: 10.1111/bjh.16494

49 Yoon SE, Kim SJ, Yoon DH, Koh Y, Mun Y, Do YR, Choi YS, Yang DH, Kim MY, Lee G, Suh C, Ko YH and Kim WS: A phase II study of ibrutinib in combination with rituximabcyclophosphamide-doxorubicin hydrochloride-vincristine sulfateprednisone therapy in Epstein-Barr virus-positive, diffuse large B cell lymphoma (54179060LYM2003: IVORY study): results of the final analysis. Ann Hematol 99(6): 1283-1291, 2020. PMID: 32333154. DOI: $10.1007 / \mathrm{s} 00277-020-04005-6$

50 Morscio J and Tousseyn T: Recent insights in the pathogenesis of post-transplantation lymphoproliferative disorders. World $\mathrm{J}$ Transplant 6(3): 505-516, 2016. PMID: 27683629. DOI: 10.5500/ wjt.v6.i3.505
51 Georgiou K, Chen L, Berglund M, Ren W, de Miranda NFCC, Lisboa S, Fangazio M, Zhu S, Hou Y, Wu K, Fang W, Wang X, Meng B, Zhang L, Zeng Y, Bhagar G, Nordenskjöld M, Sundström C, Enblad G, Dalla-Favera R, Zhang H, Teixeira MR, Pasqualucci L, Peng R and Qiang P: Genetic basis of PD-L1 overexpression in diffuse large B-cell lymphomas. Blood 127(24): 3026-3034, 2016. PMID: 27030389. DOI: 10.1182/blood-2015$12-686550$

52 Vincent-Fabert C, Roland L, Zimber-Strobl U, Feuillard J and Faumont N: Pre-clinical blocking of PD-L1 molecule, which expression is down regulated by NF-kB, JAK1/JAK2 and BTK inhibitors, induces regression of activated B-cell lymphoma. Cell Commun Signal 17(1): 89, 2019. PMID: 31382969. DOI: 10.1186/s12964-019-0391-x

53 Kline J, Godfrey J and Ansell SM: The immune landscape and response to immune checkpoint blockade therapy in lymphoma. Blood 135(8): 523-533, 2020. PMID: 31790142. DOI: 10.1182/ blood 2019000847

54 Xu-Monette Z, Zhou J and Young K: PD-1 expression and clinical PD-1 blockade in B-cell lymphomas. Blood 131(1): 68-83, 2018. PMID: 29118007. DOI: 10.1182/blood-2017-07-740993

55 Grimm KE and O'Malley DP: Aggressive B cell lymphomas in the 2017 revised WHO classification of tumors of hematopoietic and lymphoid tissues. Ann Diagn Pathol 38: 6-10, 2019. PMID: 30380402. DOI: 10.1016/j.anndiagpath.2018.09.01

Received August 5, 2020

Revised August 24, 2020

Accepted August 25, 2020 